\title{
Does Linear Canopy Openings in a Lowland Atlantic Tropical Forest Cause Edge Effects on Seedling Communities?
}

\author{
Pablo J. F. Pena Rodrigues, ${ }^{1,2}$, Mariana A. Iguatemy', Marcelo T. Nascimento ${ }^{2}$ \\ ${ }^{1}$ Instituto de Pesquisas Jardim Botanico do Rio de Janeiro, Rio de Janeiro-RJ, Brazil \\ ${ }^{2}$ Universidade Estadual do Norte Fluminense Darcy Ribeiro, Campos dos Goytacazes-RJ, Brazil

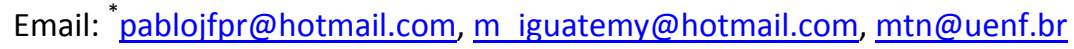

Received 11 September 2014; revised 12 October 2014; accepted 22 October 2014

Copyright (C) 2014 by authors and Scientific Research Publishing Inc.

This work is licensed under the Creative Commons Attribution International License (CC BY). http://creativecommons.org/licenses/by/4.0/

c) (i) Open Access

\begin{abstract}
Edge effects and linear canopy openings may change ecological patterns and processes on forests. Here we investigate if these openings in a lowland Brazilian Atlantic forest cause edge effects on seedlings. We sampled seedling communities at forest edges near to two linear canopy openings (gas pipeline and power line) and in interiors far from edges. Comparisons between the seedling communities were performed to access edge effects. Density and basal area patterns were compared using, hierarchical two-way ANOVAs and the number of newly germinated seedlings, mortality and resprouts were compared by one-way ANOVAs. The results showed that edge effects of linear canopy openings affect seedling communities leading to low densities on edges that showed less favorable conditions for arrival, establishment and initial survival. The basal area patterns were not affected by edge effects apparently by the resistance of the seedlings that have more than $4 \mathrm{~mm}$ diameter. Therefore, linear canopy openings caused edge effects, which determine low seedling densities on edges. However this pattern is not due to increase mortality on these edges, but probably caused by the reduction on germination and establishment.
\end{abstract}

\section{Keywords}

Forest Regeneration, Fragmentation, Disturbance, Human-Modified Habitats, Secondary Forests

\section{Introduction}

Habitat loss and fragmentation are among the most evident threats to biodiversity and the related edge effects may drastically change ecosystems structure and function [1]-[6]. The Brazilian Atlantic forest, one of the world's

\footnotetext{
${ }^{*}$ Corresponding author.
} 
species-rich ecosystems [7], was reduced to $11.7 \%$ of its original cover [8] and currently is restricted to remnant fragments [9] [10] that are potentially highly exposed to several threats. In this case, edge effects are important drivers of change when considering the physical and biotic alterations related to such artificial boundaries. Changes in resource availability, species interactions and disturbance patterns are expected in such human-modified habitats. Many studies have shown the consequences of edges effects in tropical forests [11]-[16], but they are almost unknown the precise consequences on Atlantic forest regeneration patterns and, only recently, it was found that the creation of linear canopy openings caused edge effects on understory communities [17].

Plant communities may also vary in impact resistance and resilience, and then in the human-induced complex scenario, it is also expected that local edge effects are site-specific and related to disturbance history. On the other hand linear canopy openings, such as gas pipeline and power lines are relatively controlled field experiments and allow us inferences about edge effects that are probably not confounded by other disturbances [17] [18]. Here we analyzed edge effect patterns on Atlantic forest woody seedlings. In this study, seedling communities at forest edges, adjacent to the linear canopy openings, and thus gas pipeline and power line, were compared with forest interiors used as control sites.

\section{Material and Methods}

\subsection{Study Area}

The União Biological Reserve (hereafter UNIÃO) is located in the state of Rio de Janeiro, southeastern Brazil $\left(22^{\circ} 27^{\prime} 30 " \mathrm{~S}, 42^{\circ} 02^{\prime} 14^{\prime \prime} \mathrm{W}\right)$ inside one area of 2548 hectares. This protected area was created in 1998 mainly to preserve lowland Atlantic Forest remnants and the endangered Golden Lion Tamarin (Leontopithecus rosalia L.). Local climate is tropical wet, corresponding to Köeppen's Am and the mean annual precipitation is around $1600 \mathrm{~mm}$, with a slight dry season between April and September and the mean annual temperature is $22^{\circ} \mathrm{C}$. The local vegetation is the typical Brazilian lowland Atlantic rain forest [19] with a high richness of late-successional tree species and a high basal area [18]. However, native habitats in some areas were replaced by anthropogenic scenarios like two linear canopy openings called here the gas pipeline (GP) and the power line (PL). The GP was created in the 1980s, it is $25 \mathrm{~m}$ wide, and was frequently maintained to keep only a herbaceous vegetation. The power line opening was created in the 1960s, it is $100 \mathrm{~m}$ wide, and is covered by early successional vegetation. Therefore, forest edges close to these canopy openings are exposed to contrasting matrix vegetation.

\subsection{Sampling Design}

In November of the year 2000, twelve plots $(20 \mathrm{~m} \times 50 \mathrm{~m})$ subdivided into forty $(5 \mathrm{~m} \times 5 \mathrm{~m})$ sub-plots were placed at UNIÃO forests. Four plots were located in Gas pipeline forest edges (sites GP) and the other four in Power line forest edges (sites PL). Remaining four plots were placed at forest interiors ( $400 \mathrm{~m}$ far from any edge; sites INTERIOR). Seedlings, thus, individuals that have less than $1 \mathrm{~m}$ height and/or $10 \mathrm{~mm}$ diameter, were sampled using 10 micro-plots $(2 \mathrm{~m} \times 1 \mathrm{~m})$, stratified-randomly distributed within each sub-plot. Inside the microplots each individual plant had its diameter and height measured. Qualitative aspects of the individuals such as newly germinated seedlings (definition, see [20]) and resprouting were also observed. After one year, thus, in November 2001, all individuals were re-measured and plots reanalyzed.

\subsection{Comparisons}

Comparisons between seedlings density and basal area per micro-plot were performed using, hierarchical twoway ANOVAs (plot nested within site) followed by Tukey (HSD, $\mathrm{p}<0.05$ ) a posteriori tests [21]. All data without normal distribution were prior transformed to $\log _{10}(x+1)$. The number of newly germinated seedlings (in the years 2000 and 2001), recruitment (2000-2001), one year mortality (period 2000-2001 year; deads) and resprouts (in 2001 year) in each plot was obtained by sum of all individuals inside the micro-plots and these totals per plot were compared by one-way ANOVAs followed by Tukey (HSD, $\mathrm{p}<0.05$ ) a posteriori tests [22].

\section{Results}

The GP and PL edges always showed lower seedling densities when compared to the INTERIOR. In the years 2000 and 2001, recruitment was extremely low in edge sites, even excluding the expected pattern of high mortality of newly germinated seedlings. However, the mean basal area was similar between the sites, suggesting 
that the local seedlings are able to resprout or resist even facing the edge effects. Moreover, seedlings with more than $4 \mathrm{~mm}$ diameter apparently were more resistant to direct damage or edge effects and this fact was very important to the basal area patterns (Table 1).

\section{Discussion}

Edge effects are important ecological filters for plant establishment, survival, and growth [11] [23] and here the edge sites, thus, gas pipeline (GP) and power line (PL), showed less favorable conditions for establishment and initial survival of seedlings. Some years after the fragmentation, in the phase called "stagnation", seedling densities at the edges tend to be lower when compared to the forest interior [24]-[28]. These reductions may be caused by several factors such as the small recruitment [29] which can be originated from biotic [26] [30] or abiotic causes mainly derived from changes in disturbance regimes, species interactions and resource availability [2] [14] [31].

Nevertheless, lower densities on edges may also be caused by limitations on the arrival of seeds. On tropical rainforests the dispersal in space, mediated by animals, may be negatively affected by the fragmentation [32]-[35]. In small forest fragments may also be a lower recruitment of seedlings of animal dispersed species [32]. In fact in some Atlantic Forest areas, an interruption in the dispersal processes by vertebrates may lead to a dominance of pioneer species with small seeds especially on edges [36]. The pattern of more abundance of disturbance-tolerant species in edges was previously observed for understorey plants [17] and trees [18] at the União Biological Reserve. Therefore, these linear canopy openings may contribute to change continually and permanently the patterns of occurrence of dispersal fauna, resulting in changes in the arrival of seeds in the adjacent forests.

The small seedlings are very susceptible to disturbances [37] [38] then it would be expected that these individuals had higher mortality [39]. On the other hand, observing the habitat, younger edges and contrasting limits (edge vs. matrix) in general have more intense effects on remnants [11] [40] [41]. Thus, gas pipeline (GP) showed the most unfavorable condition for seedlings with observed high mortality and lower recruitment.

\section{Conclusion}

Linear canopy openings may cause edge effects, promoting low seedling densities on edges by the reduction on germination and establishment. Therefore, these types of edge effects are distinct from those observed in typicaltropical forest fragments where the low densities are caused mainly by increase in mortality.

Table 1. Comparisons between seedling communities on the localities forest interior (IN), gas pipeline (GP) and power line (PL) at União Biological Reserve, Rio de Janeiro, Brazil. Densities (n) and basal areas ( $\left.\mathrm{mm}^{2}\right)$ per micro-plot were compared by two-way ANOVAs (nesting plot in locality). The number of individuals newly germinated, recruited, deads and resprouted per plot were compared by one way ANOVAs. Marked $\left(^{*}\right) \mathrm{F}$ values indicates significant differences between localities and means ( \pm standard deviation) followed by the same letter (a or b, on the lines) do not differ significantly (Tukey-type test, $\mathrm{p}<0.05)$.

\begin{tabular}{ccccc}
\hline Locality & Forest interior & Gas pipeline & Power line & ANOVA \\
\hline Mean density micro-plot ${ }^{-1}(\mathrm{n})$ & $9.7 \mathrm{a} \pm 0.7$ & $5.6 \mathrm{~b} \pm 1.2$ & $6.3 \mathrm{~b} \pm 0.8$ & $\mathrm{~F}(2,108)=6.43^{*} ; \mathrm{p}<0.000$ \\
Mean basal area micro-plot ${ }^{-1}\left(\mathrm{~mm}^{2}\right)$ & $122 \pm 1.2$ & $103 \pm 3.4$ & $106 \pm 2.3$ & $\mathrm{~F}(2,108)=0.21 ; \mathrm{p}<0.807$ \\
Newly germinated (n) $2000 \mathrm{yr}$ & $39.7 \mathrm{a} \pm 21$ & $6.0 \mathrm{~b} \pm 4.5$ & $3.2 \mathrm{~b} \pm 0.9$ & $\mathrm{~F}(2,9)=9.95^{*} ; \mathrm{p}<0.630$ \\
$2001 \mathrm{yr}$ & $16.7 \pm 8.4$ & $3.5 \pm 5.6$ & $6.2 \pm 5.7$ & $\mathrm{~F}(2,9)=4.3 ; \mathrm{p}<0.048$ \\
${ }^{*}$ Recruitment (n) & $29.7 \mathrm{a} \pm 14.5$ & $6.0 \mathrm{~b} \pm 6.0$ & $14 \mathrm{ab} \pm 9.9$ & $\mathrm{~F}(2,9)=5.0^{*} ; \mathrm{p}<0.034$ \\
${ }^{*}$ Deads (n) & $41.2 \mathrm{a} \pm 12.3$ & $26 \mathrm{ab} \pm 20.9$ & $9.7 \mathrm{~b} \pm 7.7$ & $\mathrm{~F}(2,9)=4.58^{*} ; \mathrm{p}<0.042$ \\
Resprouts (n) & $6.2 \pm 3.3$ & $11.5 \pm 5.8$ & $13.7 \pm 8.2$ & $\mathrm{~F}(2,9)=1.58 ; \mathrm{p}<0.257$ \\
\hline
\end{tabular}

Data without normal distribution were transformed to $\log _{10}(x+1)$. For unequal n's the Tukey test used was Spojotvoll/Stoline. * Recruitment and *Deads are based on one year period (2000 to 2001 year). 


\section{Acknowledgements}

We thank Dr. Andrea Costa and one anonymous referee for valuable suggestions which improved the manuscript. We are very grateful to Adilson da Silva and Adilson Pintor for fieldwork support. We also thank the Fundação Flora and PETROBRAS for financial support (research grant number 6000.0023998.06.02 to Programa Mata Atlântica/Pablo J.F.P. Rodrigues), the Instituto Chico Mendes de Conservação da Biodiversidade (ICMBio) and the União Biological reserve staff for logistical facilities, A. Costa for linguistic advice, and UENF/FENORTE for granting a Phd's fellowship to P.J.F.P. Rodrigues.

\section{References}

[1] Lovejoy, T.E., Bierregaard-Jr., R.O., Rylands, A.B., Malcon, J.R., Quintela, C.E., Harpe, L.H., Brown Jr., K.S., Powell, A.H., Powell, G.V.N., Schubart, H.O.R. and Hays, M.B. (1986) Edge and Other Effects of Isolation on Amazon Forest Fragments. In: Soulé, M.E., Ed., Conservation Biology: The Science of Scarcity and Diversity, Sinauer Associates, Sunderland, 257-285.

[2] Saunders, D.A., Hobbs, R.J. and Margules, C.R. (1991) Biological Consequences of Ecosystem Fragmentation: A Review. Conservation Biology, 5, 18-32. http://dx.doi.org/10.1111/j.1523-1739.1991.tb00384.x

[3] Malcon, J.R. (1994) Edge Effects in Central Amazonia Forest Fragments. Ecology, 75, 2438-2445. http://dx.doi.org/10.2307/1940897

[4] Murcia, C. (1995) Edge Effects in Fragmented Forests: Implications for Conservation. Trends in Ecology and Evolution, 10, 58-62. http://dx.doi.org/10.1016/S0169-5347(00)88977-6

[5] Oliveira-Filho, A.T., Mello, J.M. and Scolforo, J.R.S. (1997) Effects of Past Disturbance and Edges on Tree Community Structure and Dynamics within a Fragment of Tropical Semideciduous Forest in South-Eastern Brazil. Plant Ecology, 131, 45-66. http://dx.doi.org/10.1023/A:1009744207641

[6] Laurance, W.F. (2002) Hyperdynamism in Fragmented Habitats. Journal of Vegetation Science, 13, 595-602. http://dx.doi.org/10.1111/j.1654-1103.2002.tb02086.x

[7] Peixoto, A.L. and Gentry, A. (1990) Diversidade e composição florística da mata de tabuleiro na Reserva Florestal de Linhares (Espírito Santo, Brasil). Revista Brasileira de Botânica, 13, 19-25.

[8] Ribeiro, M.C., Metzger, J.P., Martensen, A.C., Ponzoni, F.J. and Hirota, M.M. (2009) The Brazilian Atlantic Forest: How Much Is Left, and How Is the Remaining Forest Distributed? Implications for Conservation. Biological Conservation, 142, 1141-1153. http://dx.doi.org/10.1016/j.biocon.2009.02.021

[9] Myers, N., Mittermeier, R.A., Mittermeier, C.G., Fonseca, G.A.B. and Kent, J. (2000) Biodiversity Hotspots for Conservation Priorities. Nature, 403, 853-858. http://dx.doi.org/10.1038/35002501

[10] Morellato, L.P.C. and Haddad, C.F.B. (2000) Introduction: The Brazilian Atlantic Forest. Biotropica, 32, 786-792. http://dx.doi.org/10.1111/j.1744-7429.2000.tb00618.x

[11] Williams-Linera, G. (1990) Vegetation Structure and Environmental Conditions of Forest Edges in Panama. Journal of Ecology, 78, 356-373. http://dx.doi.org/10.2307/2261117

[12] Bierregaard, R.O., Lovejoy, T.E., Kapos, V., Dos Santos, A.A. and Hutchings, R.W. (1992) The Biological Dynamics of Tropical Rainforest Fragments. BioScience, 42, 859-866. http://dx.doi.org/10.2307/1312085

[13] Kapos, V., Wandelli, E., Camargo, J.L. and Ganade, G. (1997) Edge-Related Changes in Environment and Plant Responses Due to Forest Fragmentation in Central Amazonia. In: Laurance, W.F. and Bierregaard-Jr., R.O., Eds., Tropical Forest Remnants: Ecology, Management and Conservation of Fragmented Communities, Chicago University Press, Chicago, 33-44.

[14] Laurance, W.F., Ferreira, L.V., Rankin-de-Merona, J.M., Laurance, S.G., Hutchings, R.W. and Lovejoy, T.E. (1998) Effects of Forest Fragmentation on Recruitment Patterns in Amazonian Tree Communities. Conservation Biology, 12, 460-464. http://dx.doi.org/10.1046/j.1523-1739.1998.97175.x

[15] Laurance, W.F., Pérez-Salicrup, D., Delamônica, P., Fearnside, P.M., D’angelo, S., Jerozolinski, A., Pohl, L. and Lovejoy, T.E. (2001) Rain Forest Fragmentation and the Structure of Amazonian Liana Communities. Ecology, 82, 105116. http://dx.doi.org/10.1890/0012-9658(2001)082[0105:RFFATS]2.0.CO;2

[16] Oliveira, M.A., Grillo, A.S. and Tabarelli, M. (2004) Forest Edge in the Brazilian Atlantic Forest: Drastic Changes in Tree Species Assemblages. Oryx, 38, 389-394. http://dx.doi.org/10.1017/S0030605304000754

[17] Prieto, P.V., Sansevero, J.B.B., Garbin, M.L., Braga, J.M.A. and Rodrigues, P.J.F.P. (2014) Edge Effects of Linear Canopy Openings on Understory Communities in a Lowland Atlantic Tropical Forest. Applied Vegetation Science, 17, 121-128. http://dx.doi.org/10.1111/avsc.12043

[18] Rodrigues, P.J.F.P. (2004) A vegetação da Reserva Biológica União e os efeitos de borda na Mata Atlântica fragmentada. 
Tese de doutorado, Universidade Estadual do Norte Fluminense, UENF, Campos dos Goytacazes, RJ.

[19] Veloso, H.P., Rangel-Filho, A.L.R. and Lima, J.C.A. (1991) Classificação da vegetação brasileira, adaptada a um sistema universal. IBGE, Rio de Janeiro.

[20] Garwood, N.C. (1996) Functional Morphology of Tropical Tree Seedlings. In: Swaine, M.D., Ed., The Ecology of Tropical Forest Tree Seedling, UNESCO, Parthenon, Paris, Carnforth, 59-129.

[21] Sahai, H. and Ageel, M.I. (2000) The Analysis of Variance: Fixed, Random and Mixed Models. Birkhäuser Boston, Boston. http://dx.doi.org/10.1007/978-1-4612-1344-4

[22] Zar, J. (1999) Biostatistical Analysis. 4th Edition, Prentice Hall, Englewood Cliffs.

[23] Sizer, N. and Tanner, E.V.J. (1999) Responses of Woody Plant Seedlings to Edge Formation in a Lowland Tropical Rainforest, Amazonia. Biological Conservation, 91, 135-142. http://dx.doi.org/10.1016/S0006-3207(99)00076-2

[24] Turton, S.M. and Freiburger, H.J. (1997) Edge and Aspect Effects on the Microclimate of a Small Tropical Forest Remnant on the Atherton Tableland, Northeastern Australia. In: Laurence, W.F. and Bierregaard, R.O., Eds., Tropical Forest Remnants, The University of Chicago, Chicago, 45-54.

[25] Benitez-Malvido, J. (1998) Impact of Forest Fragmentation on Seedling Abundance in a Tropical Rain Forest. Conservation Biology, 12, 380-389. http://dx.doi.org/10.1046/j.1523-1739.1998.96295.x

[26] Benítez-Malvido, J. and Lemus-Albor, A. (2005) The Seedling Community of Tropical Rain Forest Edges and Its Interaction with Herbivores and Pathogens. Biotropica, 37, 301-313. http://dx.doi.org/10.1111/j.1744-7429.2005.00031.x

[27] Tomimatsu, H. and Ohara, M. (2004) Edge Effects on Recruitment of Trillium camschatcense in Small Forest Fragments. Biological Conservation, 117, 509-519. http://dx.doi.org/10.1016/j.biocon.2003.08.010

[28] Bach, C.E., Kelly, D. and Hazlett, B.A. (2005) Forest Edges Benefit Adults, but Not Seedlings, of the Mistletoe Alepis flavida (Loranthaceae). Journal of Ecology, 93, 79-86. http://dx.doi.org/10.1111/j.1365-2745.2004.00961.x

[29] Jules, E.S. (1998) Habitat Fragmentation and Demographic Change for a Common Plant: Trillium in Old-Growth Forest. Ecology, 79, 1645-1656. http://dx.doi.org/10.1890/0012-9658(1998)079[1645:HFADCF]2.0.CO;2

[30] Cadenasso, M.L. and Pickett, T.A. (2000) Linking Forest Edge Structure to Edge Function: Mediation of Herbivore Damage. Journal of Ecology, 88, 31-44. http://dx.doi.org/10.1046/j.1365-2745.2000.00423.x

[31] Ries, L., Fletcher, R.J., Battin, J. and Sisk, T.D. (2004) Ecological Responses to Habitat Edges. Annual Review of Ecology and Systematics, 35, 491-522. http://dx.doi.org/10.1146/annurev.ecolsys.35.112202.130148

[32] Cordeiro, N.J. and Howe, H.F. (2001) Low Recruitment of Trees Dispersed by Animals in African Forest Fragments. Conservation Biology, 15, 1733-1741. http://dx.doi.org/10.1046/j.1523-1739.2001.99579.x

[33] Cordeiro, N.J. and Howe, H.F. (2003) Forest Fragmentation Severs Mutualism between Seed Dispersers and an Endemic African Tree. Proceedings of the National Academy of Sciences of the United States of America, 100, 1405214056. http://dx.doi.org/10.1073/pnas.2331023100

[34] Galetti, M., Donatti, C.I., Pires, A.S., Guimarães Jr., P.R. and Jordano, P. (2006) Seed Survival and Dispersal of an Endemic Atlantic Forest Palm: The Combined Effects of Defaunation and Forest Fragmentation. Botanical Journal of the Linnean Society, 151, 141-149. http://dx.doi.org/10.1111/j.1095-8339.2006.00529.x

[35] Cramer, J.M., Mesquita, R.C.G., Bentos, T.V., Moser, B. and Williamson, G.B. (2007) Forest Fragmentation Reduces Seed Dispersal of Duckeodendron cestroides, a Central Amazon Endemic. Biotropica, 39, 709-718. http://dx.doi.org/10.1111/j.1744-7429.2007.00317.x

[36] Melo, F.P.L., Dirzo, R. and Tabarelli, M. (2006) Biased Seed Rain in Forest Edges. Biological Conservation, 132, 5060. http://dx.doi.org/10.1016/j.biocon.2006.03.015

[37] Harper, J.L. (1977) Population Biology of Plants. Academic Press, London, 842.

[38] Whitmore, T.C. (1997) Tropical Forest Disturbance, Disappearance and Species Loss. In: Laurance, W.F. and Bierregaard, R.O., Eds., Tropical Forest Remnants: Ecology, Management and Conservation of Fragmented Communities, The University of Chicago Press, Chicago, 3-12.

[39] Scariot, A. (2000) Seedling Mortality by Litterfall in Amazonian Forest Fragments. Biotropica, 32, 662-669. http://dx.doi.org/10.1646/0006-3606(2000)032[0662:SMBLIA]2.0.CO;2

[40] Mesquita, R.C.G., Delamonica, P. and Laurance, W.F. (1999) Effect of Surrounding Vegetation on Edge-Related Tree Mortality in Amazonian Forest Fragments. Biological Conservation, 91, 129-134. http://dx.doi.org/10.1016/S0006-3207(99)00086-5

[41] Harper, K.A., Macdonald, S.E., Burton, P.J., Chen, J., Brosofske, K.D., Saunders, S.C., Euskirchen, E.S., Roberts, D., Jaiteh, M.S. and Essen, P.E. (2005) Edge Influence on Forest Structure and Composition in Fragmented Landscapes. Conservation Biology, 19, 768-782. http://dx.doi.org/10.1111/j.1523-1739.2005.00045.x 
Scientific Research Publishing (SCIRP) is one of the largest Open Access journal publishers. It is currently publishing more than 200 open access, online, peer-reviewed journals covering a wide range of academic disciplines. SCIRP serves the worldwide academic communities and contributes to the progress and application of science with its publication.

Other selected journals from SCIRP are listed as below. Submit your manuscript to us via either submit@scirp.org or Online Submission Portal.
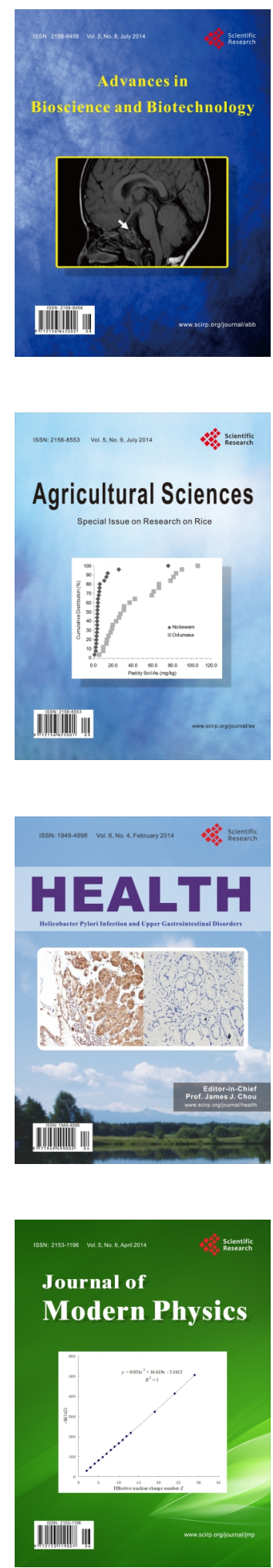
